\title{
Performance analysis of AS-SOFC fuel cell combining single and sinusoidal flow field: numerical study
}

\author{
Sabrina Horr ${ }^{1,}{ }^{*}$, Hocine Mohcene ${ }^{2}$, Hamza Bouguettaia ${ }^{2}$, and Hocine Ben Moussa ${ }^{3}$ \\ ${ }^{1}$ Department of Renewable Energies, Laboratory of New and Renewable Energies in Arid Zones (LENREZA), Kasdi Merbah \\ University, Ouargla, Algeria \\ ${ }^{2}$ Department of Physics, Laboratory of New and Renewable Energies in Arid Zones (LENREZA), Kasdi Merbah University, \\ Ouargla, Algeria \\ 3 Department of Mechanical Engineering, Hadj Lahkder University, Batna, Algeria
}

Received: 22 February 2021 / Received in final form: 6 May 2021 / Accepted: 8 May 2021

\begin{abstract}
The performance of a solid oxide fuel cell (SOFC) was examined using 3D computational fluid dynamics to model mass and heat flows inside the channels. In the present investigation, a SOFC fuel cell with a new flow field based on a sinusoidal flow has been studied. The latter was tested and compared with a single flow using ANSYS FLUENT. The obtained results showed that at a given operating voltage, the maximum power for the sinusoidal and the single flow fields were 1.43 and $1.35 \mathrm{~W} / \mathrm{cm}^{2}$, respectively. By taking in addition, into account the concentration, activation and Ohmic losses; it was noticed that the distribution of velocity and temperature for the sinusoidal flow led to bettered results. Furthermore, it was observed that the maximum use of $\mathrm{H}_{2}$ mass fraction consumed in sinusoidal and single flow field designs were $60 \%$ and $55 \%$ respectively. Similarly, the highest $\mathrm{H}_{2} \mathrm{O}$ mass fraction values produced for the sinusoidal and single flow designs were $42 \%$ and $34 \%$ respectively. This model was validated and confronted to previous data. The present results agree well with reported studies in literature.
\end{abstract}

\section{Introduction}

Nowadays, fuel cell technology is a fast growing scientific and technical field. It is in the process of constituting the core of the next industrial revolution. Recently, solid oxide fuel cells studying has attracted the attention of many researchers worldwide for clean energy production [1]. They are regarded as the most advantageous types appropriating renewable energy sources to produce electricity and provide great power density, which can be employed to versatile power generation systems [2]. SOFCs provide several advantages such as: high efficiency $[3,4]$, low emission of pollutants, working in silence [1], fuel flexibility [5], long-term stability [6], use of low-cost catalyst material [7] and the ability of utilization for cogeneration $[8,9]$. Flow channel design has a vital importance on the performance of SOFC fuel cells. Consequently, various investigations have been carried out to explore the influence of flow channels design. Amongst these, the most often mentioned model given by

\footnotetext{
* e-mail: sabrina.sabi2005@gmail.com
}

Achenbach [10] studied with time-dependent the effects of flow manifolding with utilizing differential and finite equations that allow determining heat and mass transfer in SOFCs. The researchers found that the counter-flow design has an impact in improving the performance compared to cross and co-flow. Xu et al. [11] conducted a numerical model to study the planar solid oxide electrolyzer cell (SOEC) with diverse flow forms (co-flow, counter-flow and cross-flow fields). The authors arrived at that the cross-flow design presented the best performance as it produced hydrogen the most compared to the co-flow and counter-flow under similar boundary conditions. Hawkes et al. $[12,13]$ presented 3D simulations on a SOEC stack under cross-flow configuration. They have discussed profiles of activation overpotential, temperature, operating potential, current density, Nernst potential, the gas composition of anode-side and cathode-side and hydrogen production at several deferent operating conditions of the stack using ANSYS FLUENT. Wuxi et al. [14] examined the impact of geometric parameters such as the dimension of the channel, the repeating cell height and the width of the manifold on the flow improvement. The simulation results showed that the ratio of the outlet to the inlet 
manifold width was affected significantly by the flow uniformity. Valery et al. [15] proposed a modified planar SOFC fuel cell with internal reforming. The study combined parallel flow and a new flow field design. The simulation analysis confirmed that the new modified anode configuration enhanced the performance cell and realized more uniform distribution of species concentration, velocity and current density. Saied et al. [16] compared diverse flow fields including helical, modified parallel design, traditional parallel, single-entry serpentine, double-entry serpentine and triple-entry serpentine. Their results noted that the triple-entry serpentine configuration achieved regular distributions for fuel and oxygen and presented better performance compared to other designs. Huang et al. [17] considered a new design using short guide vanes equally spaced around the feed header of the doubleinlet/single-outlet flows of rib-channel interconnects to examine the flow uniformity in several interconnectors and its impact on cell performance. They established that the new design enhanced the degree of flow uniformity in interconnects and achieved a greater value of peak power density. Lin et al. [18] developed analytically the influence of rectangular ribs on the concentration polarization of planar SOFCs. The study showed that the best design was achieved by reducing the overall concentration and Ohmic polarization of the ribs. Qiuwan et al. [19] performed numerical studies examining the performance of SOFC with and without rectangular obstacles. This attempt indicated that the fuel cell with obstacles enhanced the cell performance as it attained better current density, species concentration and temperature distribution. Clearly, the flow field configuration has a vital effect on the performance of the fuel cell and is the key factor in SOFC design optimization. Therefore, further studies on new field designs are recommended to obtain more acute and reliable results on cell performance. The main objective of the present investigation is to enhance the performance of a solid oxide fuel cell (SOFC). This study contributed and help to choose the optimum configuration for the SOFC fuel cell system manufacturers and their applications and commercialization. Thus, a new flow field based on a sinusoidal flow has been proposed and studied.

The SOFC is an electrochemical device as other fuel cells; it is a combination of a reactant (oxygen) and a fuel to produce electricity and heat. The electrochemical reaction occurring in a planar SOFC involves the following individual reactions, at the anode and cathode [20], which could be expressed as follows:

$$
\begin{aligned}
& \text { At anode } \mathrm{H}_{2}+\mathrm{O}^{2-} \rightarrow \mathrm{H}_{2} \mathrm{O}+2 \mathrm{e}^{-} \\
& \text {At cathode } \frac{1}{2} \mathrm{O}_{2}+2 \mathrm{e}^{-} \rightarrow \mathrm{O}^{2-}
\end{aligned}
$$

Overall Cell reaction $\quad \mathrm{H}_{2}+\frac{1}{2} \mathrm{O}_{2} \rightarrow \mathrm{H}_{2} \mathrm{O}+$ Heat.

The cell voltage [21-24] could be calculated from:

$$
V_{\text {cell }}=E_{\text {Nernst }}-\eta_{\text {Ohm }}-\eta_{\text {act }}-\eta_{\text {con }}
$$

where $\eta_{\text {Ohm }}, \eta_{\text {act }}$ and $\eta_{\text {con }}$ are the Ohmic, activation and concentration losses over-potential respectively [25].

The Nernst equation is also an open-circuit voltage (OCV); its value is related to the gas composition, the operating pressure, the operating temperature... etc. It is defined by equation (5) [26-29]:

$$
E_{\text {Nernst }}=-\frac{\Delta G}{2 F}+\frac{R T}{2 F} \ln \left(\frac{P_{H_{2}} \cdot P_{O_{2}}^{0.5}}{P_{H_{2} O}}\right)
$$

where $T(\mathrm{~K})$ is the operating temperature, $P(\mathrm{~Pa})$ the partial pressures of reacting species, $R\left(\mathrm{~J} \mathrm{~mol}^{-1} \mathrm{~K}^{-1}\right)$ is the gas constant, $F\left(\mathrm{C} \mathrm{mol}^{-1}\right)$ is Faraday number, and $\Delta G$ $\left(\mathrm{J} \mathrm{mol}^{-1} \mathrm{~K}^{-1}\right)$ is the Gibbs free energy.

\section{Theoretical analysis}

Mathematical models of a planar SOFC involve the governing equations of mass, momentum, energy and transport of charges. Moreover, knowledge of the ButlerVolmer equation was necessary for analyzing a model. In this study, a SOFC model was implemented in ANSYS FLUENT 18.1 software, for solving 3D and steady-state governing equations by using the finite volume approach. The applicable equations are:

- Mass conservation equation [30]:

The steady-state mass conservation equation is given as:

$$
\nabla \cdot(\varepsilon \rho v)=S_{m}
$$

The source terms, which are applicable at the interface electrode-electrolyte, are obtained from equations (8)-(10), calculated as [31-34]:

$$
\begin{gathered}
S_{m}=S_{H_{2}}+S_{H_{2} O}+S_{O_{2}} \\
S_{H_{2}}=-\left(\frac{J_{a}}{2 F}\right) M_{H_{2}} \\
S_{H_{2} O}=+\left(\frac{J_{a}}{2 F}\right) M_{H_{2} O} \\
S_{O_{2}}=-\left(\frac{J_{c}}{4 F}\right) M_{O_{2}}
\end{gathered}
$$

where $\rho\left(\mathrm{kg} \mathrm{m}^{-3}\right)$ is the gas density, $v\left(\mathrm{~m} \mathrm{~s}^{-1}\right)$ the velocity, $\varepsilon$ is the porosity and $S_{m}\left(\mathrm{~kg} \mathrm{~m}^{-3} \mathrm{~s}^{-1}\right)$ the mass source. - Momentum equation [30]:

Due to low Reynolds and the steady-state momentum conservation equation can be written as:

$$
\nabla \cdot(\varepsilon \rho v v)=-\varepsilon \nabla p+\nabla \cdot\left[\varepsilon \mu\left(\nabla v+(\nabla v)^{T}\right)\right]+\frac{\mu \varepsilon^{2}}{k_{g}} v
$$

where $k_{g}$ is the gas phase permeability $\left(\mathrm{m}^{2}\right)$ and $\mu\left(\mathrm{kg} \mathrm{m}^{-1} \mathrm{~s}^{-1}\right)$ the gas viscosity. 
- Species conservation [30-34]:

The species transport equation inside SOFC is represented by equation (12). The source terms in species equation are earlier defined in equations (8)-(10).

$$
\nabla \cdot\left(-\rho y_{i} \sum_{j \neq i}^{n} D_{e f f, i j} \nabla x_{j}+\rho v y_{i}\right)=S_{i}
$$

where $y_{i}$ is the mass fraction of species $i, D_{\text {eff }}\left(\mathrm{m}^{2} \mathrm{~s}^{-1}\right)$ the effective diffusivity coefficient between species $i$ and $j$, $S_{i}\left(\mathrm{~kg} \mathrm{~m}^{-3} \mathrm{~s}^{-1}\right)$ the source term for species $i$ and $x_{j}$ the mole fraction for species $j$.

- Energy equation [30]:

The energy conservation equation can be formulated as:

$$
\nabla \cdot\left(\varepsilon \rho c_{p} v T\right)=\nabla \cdot\left(k_{e f f} \nabla T\right)+S_{T}
$$

where $k_{\text {eff }}\left(\mathrm{W} \mathrm{m}^{-1} \mathrm{~K}^{-1}\right)$ is the coefficient of thermal conductivity, $c_{p}\left(\mathrm{~J} \mathrm{~kg}^{-1} \mathrm{~K}^{-1}\right)$ is the specific heat capacity, and $S_{T}\left(\mathrm{~W} \mathrm{~m}^{-3}\right)$ the heat source.

- Charge transport [16,31-35]:

In order to solve the charge conservation equation, electrons and ions transport should be considered. The electronic charge occurs in the electrodes and interconnectors; while, the ionic charge only exists in the electrodes and electrolyte. Thus, the governing equations for charge by Ohm's law are as follows:

Electronic charge balance:

$$
\begin{array}{cc}
\text { Anode electrode layer } & \nabla \cdot\left(\sigma_{a} \nabla \emptyset_{e l}\right)=-J_{a} A_{V} \\
\text { Cathode electrode layer } & \nabla \cdot\left(\sigma_{c} \nabla \emptyset_{e l}\right)=-J_{c} A_{V}
\end{array}
$$

Ionic charge balance:

$$
\begin{aligned}
\text { Electrolyte layer } & \nabla \cdot\left(\sigma_{e l e} \nabla \emptyset_{i 0}\right)=0 \\
\text { Anode electrode layer } & \nabla \cdot\left(\sigma_{a} \nabla \emptyset_{i 0}\right)=J_{a} A_{V} \\
\text { Cathode electrode layer } & \nabla \cdot\left(\sigma_{c} \nabla \emptyset_{i 0}\right)=J_{c} A_{V}
\end{aligned}
$$

where $\sigma_{a}$ and $\sigma_{c}\left(\mathrm{~s} \mathrm{~m}^{-1}\right)$ denote the electrical conductivity for anode and cathode, respectively. While $J_{a}$ and $J_{c}$ designating the volumetric current densities of anode and cathode; based on the Butler-Volmer equation [30] could be computed from equations (19) and (20) as:

$J_{a}=J_{0, a} A_{V}\left(\exp \left(\alpha \frac{2 F \eta_{a c t, a}}{R T}\right)-\exp \left(-(1-\alpha) \frac{2 F \eta_{a c t, a}}{R T}\right)\right)$

$J_{c}=J_{0, c} A_{V}\left(\exp \left(\beta \frac{4 F \eta_{a c t, c}}{R T}\right)-\exp \left(-(1-\beta) \frac{4 F \eta_{\text {act }, c}}{R T}\right)\right)$ where $J_{0, a}$ and $J_{0, c}\left(\mathrm{Am}^{-2}\right)$ are the reference exchange current densities of anode and cathode and $A_{V}\left(\mathrm{~m}^{2} \mathrm{~m}^{-3}\right)$ is the reactive surface area per unit volume. The reference exchange current density for anode and cathode could be calculated as [36]:

$$
\begin{gathered}
j_{0, a}=k_{a}\left(\frac{P_{h_{2}}}{P_{r e f}}\right)\left(\frac{P_{h_{2} o}}{P_{r e f}}\right) \exp \left(-\frac{E_{a c t, a}}{R T}\right) \\
j_{0, c}=k_{c}\left(\frac{P_{O_{2}}}{P_{r e f}}\right)^{0.25} \exp \left(-\frac{E_{a c t, c}}{R T}\right)
\end{gathered}
$$

$k_{a}$ and $k_{c}$ refer to the pre-exponential coefficients. $E_{a c t, a}$ and $E_{\text {act, }, c}$ are the activation energies of the anode and cathode exchange current densities, respectively. $P$ is the partial pressure of chemical species [36].

\section{Methodology}

The geometrical SOFC single cell was executed in the commercial software GAMBIT (Version 2.4.6). Figure 1 displays a schematic view of the SOFC with both sinusoidal and single flow field designs. It is constituted of the fuelflow channel, anode gas diffusion layer (A-GDL), anode catalyst layer (A-CL), electrolyte, cathode catalyst layer (C-CL), cathode gas diffusion layer (C-GDL), air-flow channel, and anode and cathode collectors.

The flow of air and fuel in the investigated cell are counter-flow. Details of the cell dimensions are given in Table 1 [37]. The subsequent step after producing cell geometry was the creation of high-quality mesh. This was done by an ANSYS WORKBENCH MESH. In order to achieve the best quality, the mesh independency was studied by creating three different meshes with 76,800 , 194,560 and 304,000 hexahedral cells. The results of mesh independency are presented in Table 2 , from which it was noticed that mesh of 304,000 cells led to a reasonable agreement when compared to the numerical results of [37]. For more details about the mesh independency, refer to $[34,38,39]$. Once the computational mesh was created, it must be imported into the solver ANSYS FLUENT 18.1. After examining the mesh file, setting the parameters, materials and defining the boundary conditions for the two geometries; as listed in Tables 3 and 4, respectively.

\section{Model validation}

The predicted current density versus voltage $(J-V)$ results for our numerical model showed an acceptable accuracy with the data obtained from references $[37,46]$ as shown in Figure 2. Nonetheless, the simulation manifested different values of current density at lower values of voltage. This is most probably due to errors and hypotheses associated with the SOFC model. Conversely, when using default parameters, the results were somewhat far from the other curves. This is why all conditions must be scrutinized and carefully readjusted according to the physical properties, to obtain results comparable to the experimental results. 

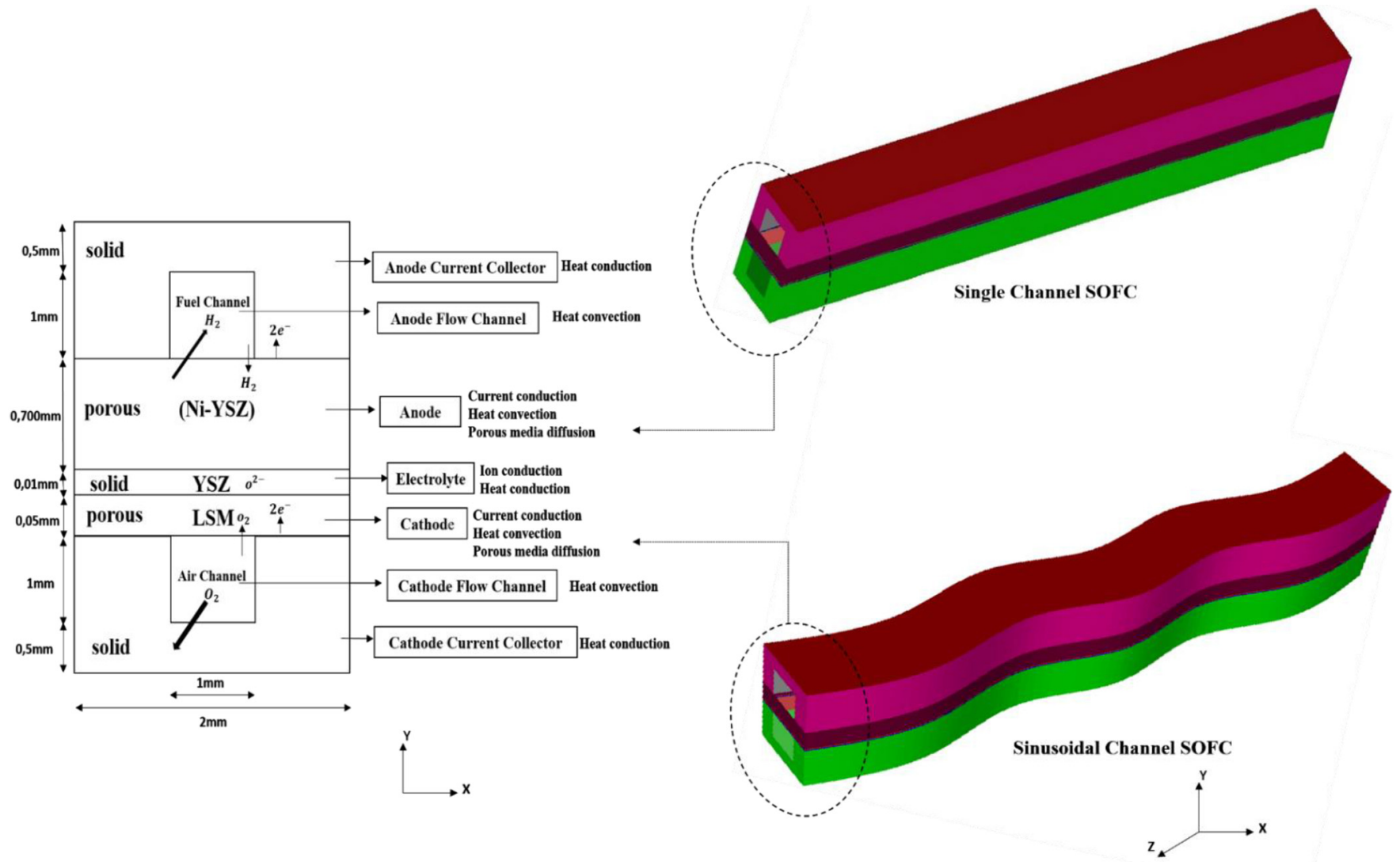

Fig. 1. Schematic view of SOFC with two different flow designs.

Table 1. Geometrical parameters.

\begin{tabular}{ll}
\hline Zone & Dimension \\
\hline Cell width $(\mathrm{mm})$ & 2 \\
Cell length $(\mathrm{mm})$ & 19 \\
Anode thickness $(\mathrm{mm})$ & 0.700 \\
Cathode thickness (mm) & 0.05 \\
Electrolyte thickness (mm) & 0.01 \\
Channel height (mm) & 1 \\
Channel width (mm) & 1 \\
Current collector height (mm) & 1.5 \\
\hline
\end{tabular}

Table 2. Mesh independency study.

\begin{tabular}{llll}
\hline No. of cells & 76,800 Hexahedral cells & 194,560 Hexahedral cells & 304,000 Hexahedral cells \\
\hline Current density at 0.7 V & 1.351322 & 1.322505 & 1.201916 \\
$\begin{array}{l}\text { Error \% compared to numerical results } \\
\text { by reference [37] }\end{array}$ & 13.33 & 11.36 & 4.16 \\
Solving time (hour) & 7 & 14 & 25 \\
\hline
\end{tabular}


Table 3. Specifications of the case study.

\begin{tabular}{|c|c|c|c|c|}
\hline & & Value & Unit & References \\
\hline \multirow{7}{*}{ Anode GDL (Ni-YSZ) } & Porosity & 0.3 & & {$[36]$} \\
\hline & Specific heat & 377 & $\mathrm{~J} \mathrm{~kg}^{-1} \mathrm{~K}^{-1}$ & {$[40,41]$} \\
\hline & Thermal conductivity & 11 & $\mathrm{~W} \mathrm{~m}{ }^{-1} \mathrm{~K}^{-1}$ & {$[40]$} \\
\hline & Density & 4200 & $\mathrm{~kg} \mathrm{~m}^{-3}$ & {$[36,41]$} \\
\hline & Anodic transfer coefficient & 2 & & {$[36,42]$} \\
\hline & Cathodic transfer coefficient & 1 & & {$[36,42]$} \\
\hline & Electron conductivity & $\frac{9.0 \times 10^{7}}{T} e^{-1150 / T}$ & $\mathrm{~s} \mathrm{~m}^{-1}$ & {$[43]$} \\
\hline \multirow{7}{*}{ Cathode GDL (LSM) } & Porosity & 0.3 & & {$[36]$} \\
\hline & Specific heat & 377 & $\mathrm{~J} \mathrm{~kg}^{-1} \mathrm{~K}^{-1}$ & {$[40,41]$} \\
\hline & Thermal conductivity & 2.37 & $\mathrm{~W} \mathrm{~m}{ }^{-1} \mathrm{~K}^{-1}$ & [40] \\
\hline & Density & 6350 & $\mathrm{~kg} \mathrm{~m}^{-3}$ & {$[36,41]$} \\
\hline & Anodic transfer coefficient & 1.4 & & {$[36,42]$} \\
\hline & Cathodic transfer coefficient & 0.6 & & {$[36,42]$} \\
\hline & Electron conductivity & $\frac{4.0 \times 10^{7}}{T} e^{-1200 / T}$ & $\mathrm{~s} \mathrm{~m}^{-1}$ & {$[43]$} \\
\hline \multirow{4}{*}{ Electrolyte (YSZ) } & Specific heat & 2000 & $\mathrm{~J} \mathrm{~kg}^{-1} \mathrm{~K}^{-1}$ & {$[40,41]$} \\
\hline & Thermal conductivity & 2.7 & 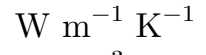 & [40] \\
\hline & Density & 6010 & $\mathrm{~kg} \mathrm{~m}^{-3}$ & {$[36,41]$} \\
\hline & Electronic conductivity & $3.34 \times 10^{4} e^{-10300 / T}$ & $\mathrm{~s} \mathrm{~m}^{-1}$ & {$[43]$} \\
\hline \multirow{4}{*}{ Interconnect (metal) } & Specific heat & 300 & $\mathrm{~J} \mathrm{~kg}^{-1} \mathrm{~K}^{-1}$ & {$[40]$} \\
\hline & Thermal conductivity & 2.2 & $\mathrm{~W} \mathrm{~m}{ }^{-1} \mathrm{~K}^{-1}$ & {$[40]$} \\
\hline & Density & 4640 & $\mathrm{~kg} \mathrm{~m}^{-3}$ & {$[36,40]$} \\
\hline & Electron conductivity & $\frac{9.3 \times 10^{5}}{T} e^{-1100 / T}$ & $\mathrm{~s} \mathrm{~m}^{-1}$ & {$[43]$} \\
\hline
\end{tabular}

Table 4. Inlet boundary conditions for the anode and cathode channels.

\begin{tabular}{llll}
\hline & Value & Unit & References \\
\hline Anode mass flow rate & $1.141 \times 10^{-8}$ & $\mathrm{~kg} \mathrm{~s}^{-1}$ & {$[37]$} \\
Cathode mass flow rate & $2.287 \times 10^{-7}$ & $\mathrm{~kg} \mathrm{~s}^{-1}$ & {$[37]$} \\
Anode inlet temperature & 1123 & $\mathrm{~K}$ & Estimated \\
Cathode inlet temperature & 1123 & $\mathrm{~K}$ & Estimated \\
Anode flow Species (mass fraction) & $97 \% \mathrm{H}_{2}, 3 \% \mathrm{H}_{2} \mathrm{O}$ & $\%$ & {$[36]$} \\
Cathode flow Species (mass fraction) & $100 \% \mathrm{O}_{2}$ & $\%$ & {$[38]$} \\
External boundaries & Adiabatic & & {$[44,45]$} \\
\hline
\end{tabular}

\section{Results and discussion}

\subsection{Distribution of velocity}

Figure 3 shows the anode velocity distribution for both flow field designs at $0.6 \mathrm{~V}$. The upmost velocity in anode channel was 10.63 and $10.35 \mathrm{~m} / \mathrm{s}$ for sinusoidal and single flow field designs, respectively, as displayed in Figure $3 \mathrm{a}$ and $\mathrm{b}$. It could be deduced that the distribution near GDL had improved, due to deflection design which increased the anode velocity and augmented the distribution mechanism.
As a result, the velocity in the anode channel for the sinusoidal design was higher than the simple single-channel which led to cell performance enhancement.

\subsection{Distribution of hydrogen and water mass fraction}

The hydrogen $\left(\mathrm{H}_{2}\right)$ mass fraction contours on the anode channel for both designs are represented in Figure 4 at $0.6 \mathrm{~V}$. The mass fraction reduction along the $\mathrm{z}$-channel is due to consumption of hydrogen by the electrochemical 
reaction. It is also found that the mass fraction diminished from 0.97 to 0.38 and 0.43 for the sinusoidal and single flow design respectively. These results signify that the reaction rates at the sinusoidal flow design are greater than those detected in the single flow. The maximum use of hydrogen mass fraction consumed in the sinusoidal and single flow field designs are $60 \%$ and $55 \%$ respectively for the operating voltage of $0.6 \mathrm{~V}$, as given in Table 5 . According to Figure 4 along with Table 5 , the sinusoidal form gave a greater level of hydrogen mass fraction. Consequently, this configuration is considered more uniform in diffusing of hydrogen mass fraction because of the best use of the active area in the CL (catalyst layer). On the other hand, increasing hydrogen mass fraction consumption increases the water

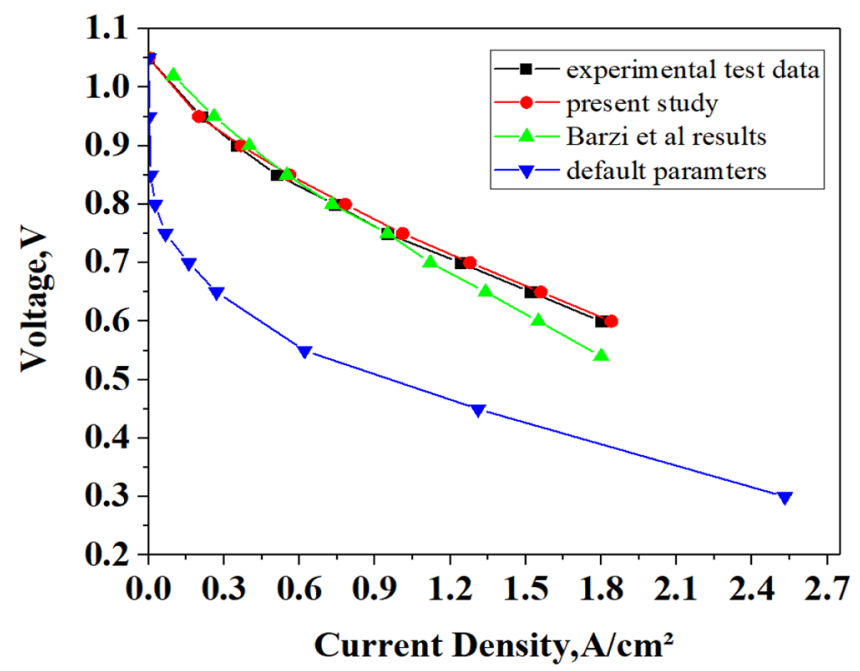

Fig. 2. $J-V$ curve comparison between present results and both the experimental and the numerical results obtained by $[37,46]$.
$\left(\mathrm{H}_{2} \mathrm{O}\right)$ mass fraction produced as displayed in Figure 5. The sinusoidal flow design has a better distribution compared to the single flow field as demonstrated in Figure 5. The highest water mass fraction values produced for the sinusoidal and single flow designs were $42 \%$ and $34 \%$ respectively for the operating voltage $0.6 \mathrm{~V}$, as shown in Table 6. This uniform distribution leads to regularly generate heat and decrease thermal stresses, suggesting that the sinusoidal cell aids in reducing losses.

\subsection{Distribution of temperature}

Figure 6 displays temperature contours for the sinusoidal and single flow field designs at $0.6 \mathrm{~V}$. An increase in temperature values is clearly observable along the cells for both designs. The sinusoidal flow led to greater values as compared to the single flow, as can be seen in the same figure. This could be explicated by the higher rate of reaction. Specifically, the highest temperatures for the sinusoidal and single flow were $1128.30 \mathrm{~K}$ and $1126.95 \mathrm{~K}$ respectively for the operating voltage $0.6 \mathrm{~V}$. For all the geometrical configurations, the highest temperature value was always located in the center of the cell which represents the electrolyte due to the counter-flow direction as marked in the literature $[47,48]$.

\subsection{Concentration, activation and ohmic overpotentials}

The mathematical model was able to predict the overpotentials inside the SOFC for both sinusoidal and single cells, which is necessary for testing their performance. As presented in the literature, there are three overpotentials, caused by various mechanisms. The concentration overpotential is based on the resistance to transport the fraction

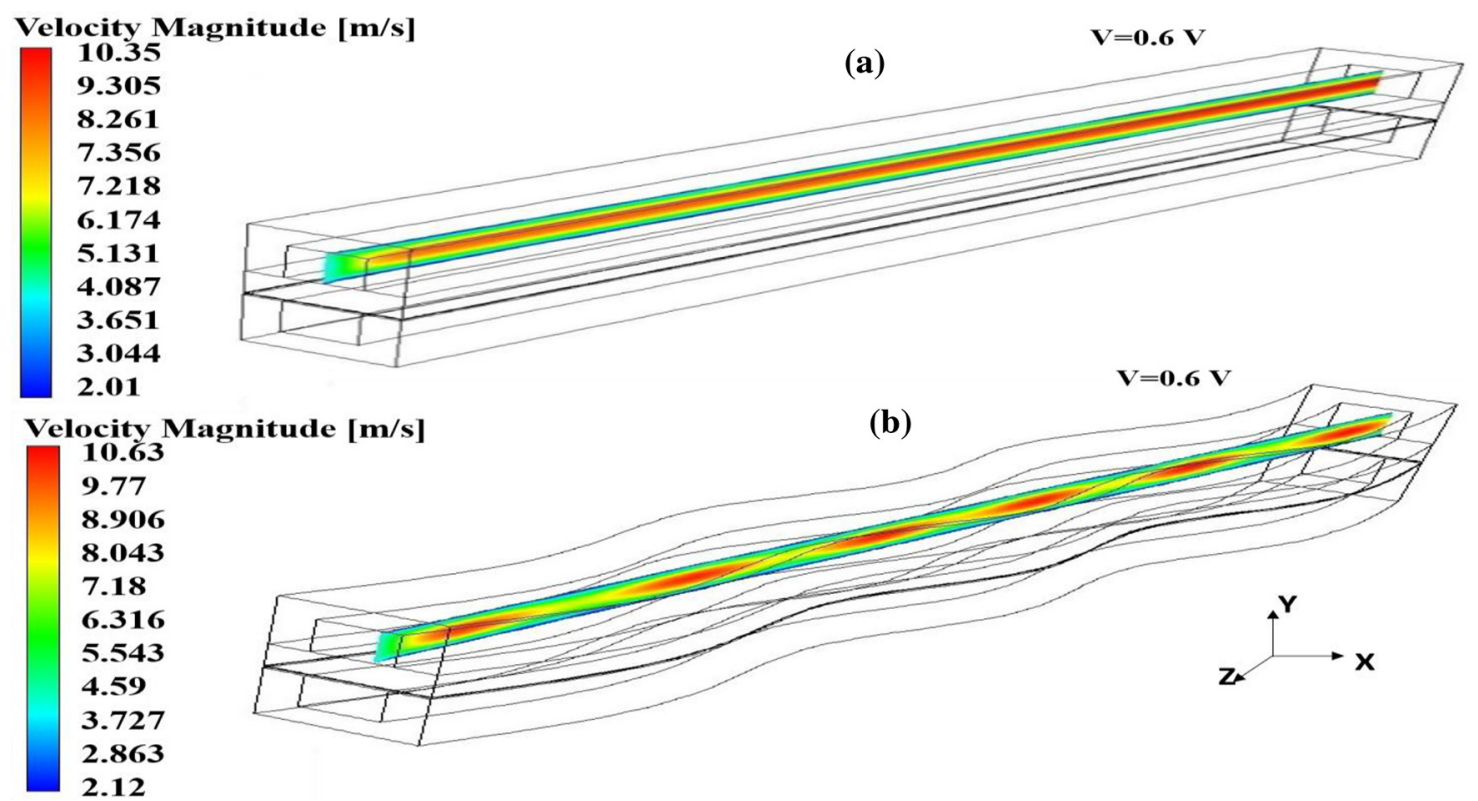

Fig. 3. Velocity distribution contour along the anode channel for two different flow designs at $0.6 \mathrm{~V}$. 


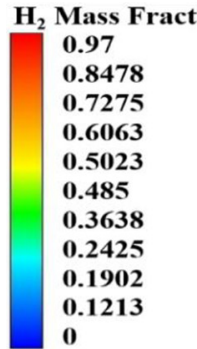

$\mathrm{H}_{2}$ Mass Fraction

0.97
0.8478
0.7275
0.6063
0.5023
0.485
0.3638
0.2425
0.1902
0.1213
0

(a)

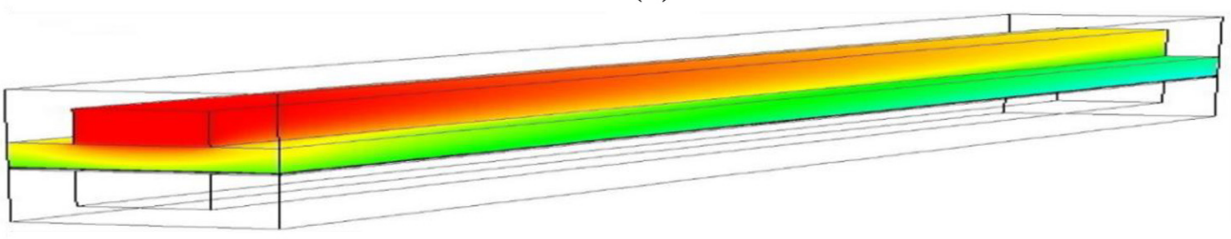

(b)

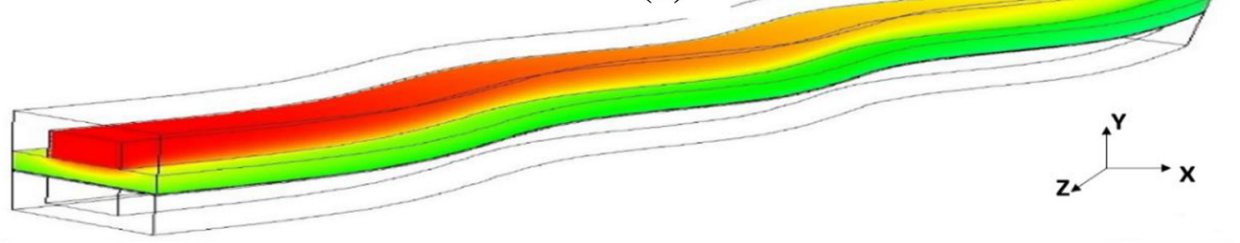

Fig. 4. Hydrogen mass fraction distribution contour along the anode channel for two different flow designs at $0.6 \mathrm{~V}$.

\begin{tabular}{|l|}
\hline $\mathbf{H}_{2} \mathrm{O}$ Mass Fraction \\
\hline $\mathbf{0 . 6 3 4 9}$ \\
$\mathbf{0 . 5 5 5 0}$ \\
$\mathbf{0 . 4 7 6 1}$ \\
$\mathbf{0 . 3 9 6 8}$ \\
$\mathbf{0 . 3 1 7 4}$ \\
$\mathbf{0 . 2 3 8 1}$ \\
$\mathbf{0 . 2 0 3 3}$ \\
$\mathbf{0 . 1 5 8 7}$ \\
$\mathbf{0 . 1 0 3 6}$ \\
$\mathbf{0 . 0 5 2 7}$ \\
$\mathbf{0 . 0 3}$
\end{tabular}

$\mathrm{H}_{2} \mathrm{O}$ Mass Fraction

0.6412

0.5761

0.5023

0.4395

0.3767

0.3139

0.2512

0.1884

0.1256

$\mathbf{0 . 0 6 2 7}$

0.03
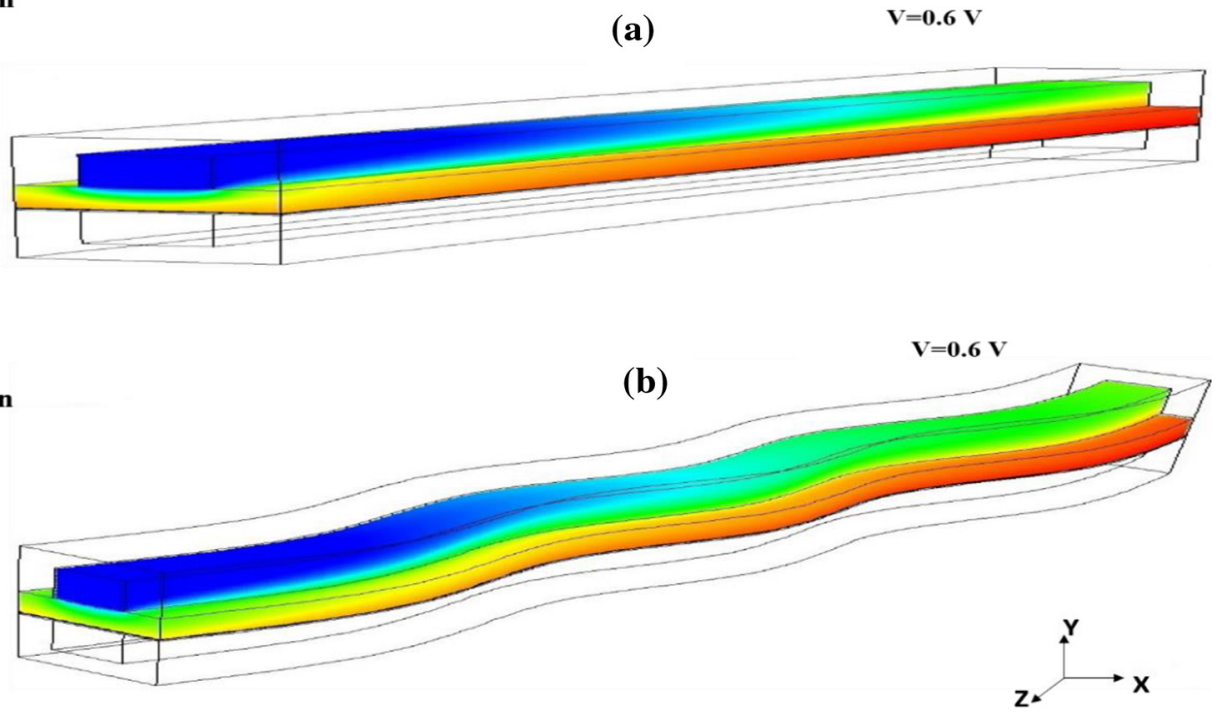

Fig. 5. Water mass fraction distribution contour along the anode channel for two different flow designs at $0.6 \mathrm{~V}$.

Table 5. Maximum value consumed of hydrogen mass fraction at the anode/ electrolyte interface.

Flow field designs

Sinusoidal flow field

Single flow field
Hydrogen mass fraction consumed at anode/electrolyte interface (\%) at $0.6 \mathrm{~V}$

$60 \%$

$55 \%$ 
Table 6. Maximum value produced of Water mass fraction at the anode/ electrolyte interface.

\begin{tabular}{ll}
\hline Flow field designs & $\begin{array}{l}\text { Water mass fraction produced at anode/electrolyte } \\
\text { interface (\%) at 0.6 V }\end{array}$ \\
\hline Sinusoidal flow field & $42 \%$ \\
Single flow field & $34 \%$ \\
\hline
\end{tabular}
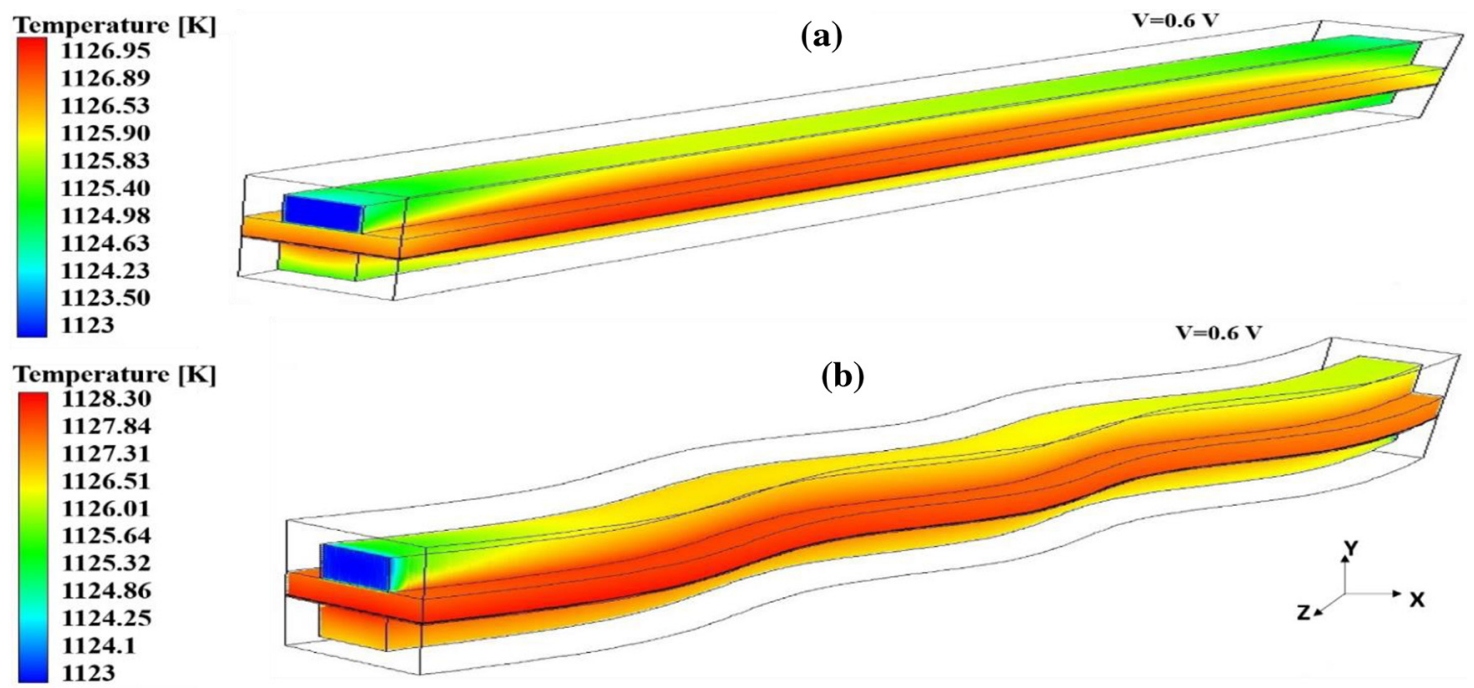

Fig. 6. Temperature distribution contour along the SOFCs cells for two different flow designs at $0.6 \mathrm{~V}$.

of reactants and oxidant. As shown in Figure $7 \mathrm{a}$ the sinusoidal flow field led to a reduction in the concentration over potential, whereas, the concentration over potential increased with the current density for both designs. The activation overpotential was slightly higher for the single cell than the sinusoidal as shown in Figure $7 \mathrm{~b}$. This is due to increasing the temperature in the sinusoidal cell which contributed in reducing activation polarization. In addition, the sinusoidal cell took part in minimizing the Ohmic overpotential as displayed in Figure 7c. This is due to the improvement of the operation temperature which raises the conductivity of the electrolyte. From the above mentioned arguments, it could be deduced that the sinusoidal cell significantly contributed to the performance enhancement and to minimization of the concentration, activation and Ohmic overpotentials compared to the single cell.

\subsection{SOFC overall performance}

Figure 8 displays the polarization $(J-V)$ and the power density curves for the two designs; from which it could be readily noticed that the sinusoidal flow design was more performable than the single flow. Additionally, the maximum power densities of the sinusoidal and single flow designs were 1.43 and $1.35 \mathrm{~W} / \mathrm{cm}^{2}$, respectively. This result indicates that the sinusoidal flow design offers the most use of the hydrogen as considered in the previous section. Moreover, the difference in performance between the two designs is well remarked at low voltages due to decreasing in the concentration losses. As a consequence, the sinusoidal flow design has contributed significantly in ameliorating the performance.

\section{Conclusions}

In this paper, two different flow designs of SOFC have been numerically developed in the software ANSYS FLUENT 18.1. The main motivation behind this research was to ameliorate the performance of SOFC fuel cells. The results obtained from this model were confronted to available research data in the literature. Simulation results including velocity distributions, gas species, temperature, concentration overpotantial, activation overpotantial, Ohmic overpotantial and cell performance for both flow designs have been introduced and discussed. The sinusoidal design gave a better distribution of velocities and temperatures than the single flow, which improved the transport of hydrogen of the cell. As a result, more water was produced at the anode channel and accordingly, the cell performance rose. On the other hand, it was established that the channel design performed an important role in enhancing the performance and decreasing the overpotantials losses of SOFC fuel cells. The CFD results indicated that, when the cell was run at high voltage, the influence of channel design on the cell performance was negligible; whereas, when treated at the low voltage the channel design influence became significant. Lastly, it could be concluded that the 

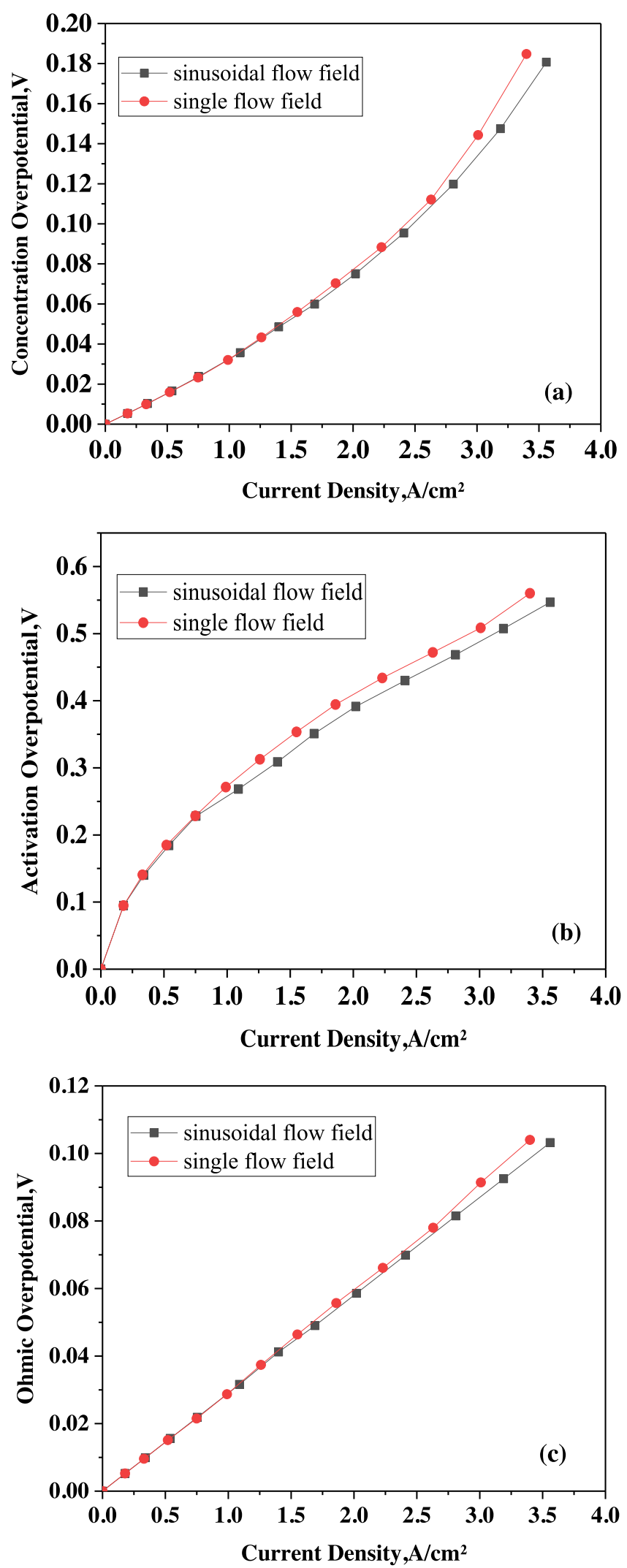

Fig. 7. (a) The concentration, (b) the activation, (c) the Ohmic overpotantials curves for two different flow field designs.

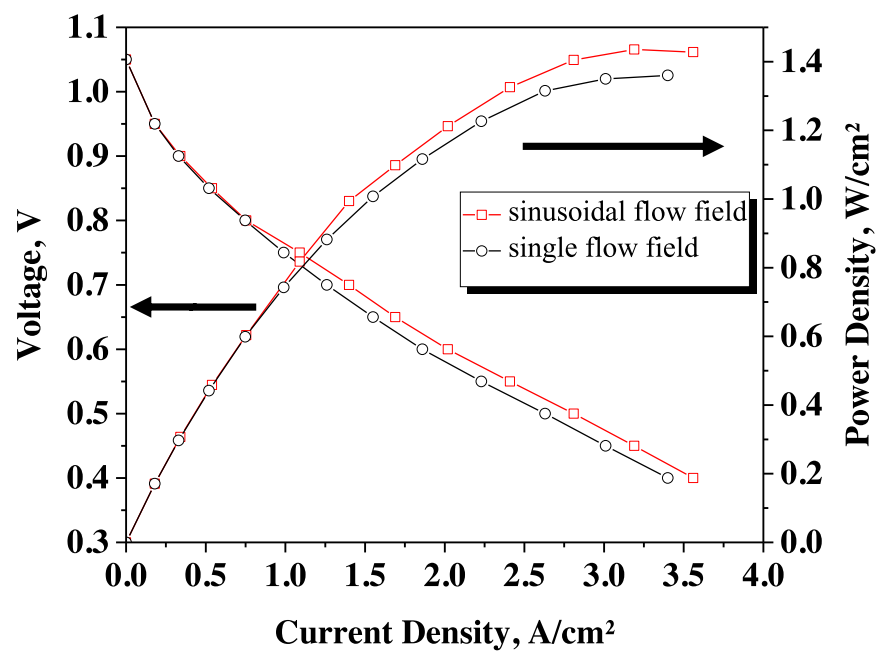

Fig. 8. The polarization curve $(J-V)$ and power density curve for two different flow designs.

sinusoidal design has greater performance than the single flow; and this could be useful in choosing the best configuration for certain applications requiring the greatest achievable performance. Future work will focus on further understanding of the porosity effects of SOFC fuel cells.

\section{Nomenclatures}

$A_{V} \quad$ Reactive surface area per unit volume, $\mathrm{m}^{2} \mathrm{~m}^{-3}$

$c_{p} \quad$ Specific heat capacity, $\mathrm{J} \mathrm{kg}^{-1} \mathrm{~K}^{-1}$

$D \quad$ Gas diffusivity, $\mathrm{m}^{2} \mathrm{~s}^{-1}$

$E_{\text {act }} \quad$ Activation energy, $\mathrm{J} \mathrm{mol}^{-1}$

$E_{\text {Nernest }}$ Nernst potential, V

$F \quad$ Faraday's constant, $\mathrm{C} \mathrm{mol}^{-1}$

$J \quad$ Current density, $\mathrm{A} \mathrm{m}^{-2}$

$j \quad$ Exchange current density, $\mathrm{A} \mathrm{m}^{-2}$

$\Delta G \quad$ Gibbs free energy change, $\mathrm{J} \mathrm{mol}^{-1} \mathrm{~K}^{-1}$

$k \quad$ Pre-exponential factor

$k_{g} \quad$ Gas phase permeability, $\mathrm{m}^{2}$

$p \quad$ Gas pressure, $\mathrm{Pa}$

$R \quad$ Universal gas constant, $\mathrm{J} \mathrm{mol}^{-1} \mathrm{~K}^{-1}$

$\mathrm{s} \quad$ Source term, $\mathrm{kg} \mathrm{m}^{-3} \mathrm{~s}^{-1}, \mathrm{~W} \mathrm{~m} \mathrm{~m}^{-3}$

T Temperature, $\mathrm{K}$

$V_{\text {cell }} \quad$ Cell potential, $\mathrm{V}$

$x \quad$ Mole fraction

$y \quad$ Mass fraction

\section{Greek letters}

0 Standard state

$A$ Transfer coefficient in anode

$B$ Transfer coefficient in cathode

$\varepsilon \quad$ Porosity

$\emptyset \quad$ Exchange potential (V)

$\eta$ Overpotential, $\mathrm{V}$

$k$ Coefficient of thermal conductivity, $\mathrm{W} \mathrm{m}^{-1} \mathrm{~K}^{-1}$ 
$\sigma \quad$ Specific conductivity, $\mathrm{s} \mathrm{m}^{-1}$

$\mu$ Fluid viscosity, $\mathrm{kg} \mathrm{m}^{-1} \mathrm{~s}^{-1}$

$v$ Velocity, $\mathrm{m} \mathrm{s}^{-1}$

$\rho$ Density, $\mathrm{kg} \mathrm{m}^{-3}$

\section{Subscripts and superscripts}

$\begin{array}{ll}a & \text { Anode } \\ \text { act } & \text { Activation } \\ c & \text { Cathode } \\ \text { conc } & \text { Concetration } \\ \text { eff } & \text { Effective } \\ e l & \text { Electronic } \\ e l e & \text { Electrolyte } \\ j & \text { Species } j \\ i & \text { Species } i \\ i_{0} & \text { Ionic } \\ \text { LSM } & \text { Cathode material } \\ \text { Ni-YSZ } & \text { Anode material } \\ \text { OCV } & \text { Open circuit voltage } \\ \text { Ohm } & \text { Ohmic } \\ \text { SOFC } & \text { Solid oxide fuel cell } \\ \text { TPB } & \text { Three phase boundary length } \\ \text { YSZ } & \text { Electrolyte material }\end{array}$

\section{References}

1. U.S. DOE, National Energy Technology Laboratory, in Fuel Cell Handbook (U.S. DOE, National Energy Technology Laboratory, 2004), 7th ed.

2. A.V. Virkar, J.W. Kim, K. Mehta, K.Z. Fung, Low temperature, high performance, planar solid oxide fuel cells and stacks (1997)

3. C. Sun, U. Stimming, Recent anode advances in solid oxide fuel cells, J. Power Sources 171, 247-260 (2007)

4. S. Revankar, P. Majumdar, in Fuel Cells Principles, Design and Analysis (Taylor \& Francis Group. LLC, 2014), 1st edn.

5. J. Wu, X. Liu, Recent development of SOFC metallic interconnect, J. Mater. Sci. Technol. 26, 293-305 (2010)

6. S. (Supramaniam) Srinivasan, Fuel Cells: From Fundamentals to Applications, Springer (2006)

7. K.H.J. Buschow, Encyclopedia of Materials: Science and Technology, Elsevier (2001)

8. M. Xu, T.S. Li, M. Yang, M. Andersson, I. Fransson, T. Larsson et al., Modeling of an anode supported solid oxide fuel cell focusing on thermal stresses, Int. J. Hydrogen Energy 1, 1-14 (2016)

9. B. Ghorbani, K. Vijayaraghavan, 3D and simplified pseudo2D modeling of single cell of a high temperature solid oxide fuel cell to be used for online control strategies, Int. J. Hydrogen Energy (2018)

10. E. Achenbach, Three-dimensional and time-dependent simulation of a planar solid oxide fuel cell stack, J. Power Sources 49, 333-348 (1994)

11. Z. Xu, X. Zhang, G. Li, G. Xiao, J. Wang, Comparative performance investigation of different gas flow configurations for a planar solid oxide electrolyzer cell, Int. J. Hydrogen Energy (2017)
12. G.L. Hawkes, J. O'Brien, C.M. Stoots, B. Hawkes, 3D CFD model of a multi-cell high-temperature electrolysis stack, Int. J. Hydrogen Energy 34, 4189-4197 (2009)

13. G.L. Hawkes, J.E. O'Brien, C.M. Stoots, J.S. Herring, M. Shahnam, CFD model of a planar solid oxide electrolysis cell for hydrogen production from nuclear energy, Nucl. Technol. 158, 132-144 (2007)

14. W. Bi, D. Chen, Z. Lin, A key geometric parameter for the flow uniformity in planar solid oxide fuel cell stacks, Int. J. Hydrogen Energy 34, 3873-3884 (2009)

15. V. Danilov, M. Tade, A CFD-based model of a planar SOFC for anode flow field design, Int. J. Hydrogen Energy 34, 8998-9006 (2009)

16. M. Saied, K. Ahmed, M. Nemat-Alla, M. Ahmed, M. ElSebaie, Performance study of solid oxide fuel cell with various flow field designs: numerical study, Int. J. Hydrogen Energy (2018)

17. C. Huang, S. Shy, C. Lee, On flow uniformity in arious interconnects and its influence to cell performance of planar SOFC, J. Power Sources 183, 205-213 (2008)

18. Z. Lin, J.W. Stevenson, M.A. Khaleel, The effect of interconnect rib size on the fuel cell concentration polarization in planar SOFCs, J. Power Sources 117, 92-97 (2003)

19. Q. Shen, L. Sun, B. Wang, Numerical simulation of the effects of obstacles in gas flow fields of a solid oxide fuel cell, Int. J. Electrochem. Sci. 14, 1698-1712 (2019)

20. S.C. Singhal, K. Kendall, High temperature Solid Oxide Fuel Cells: Fundamentals, Design, and Applications, Elsevier, New York (2003)

21. S. Cordiner, M. Feola, V. Mulone, F. Romanelli, Analysis of a SOFC energy generation system fuelled with biomass reformate, Appl. Thermal Eng. 27, 738-747 (2007)

22. S. Campanari, P. Iora, Definition and sensitivity analysis of a finite volume SOFC model for a tubular cell geometry, J. Power Sources 132, 113-126 (2004)

23. A. Luca, Experimental and numerical analysis of a radial flow solid oxide fuel cell, Int. J. Hydrogen Energy 32, 4559-4574 (2007)

24. D. Sanchez, On the effect of methane internal reforming modelling in solid oxide fuel cells, Int. J. Hydrogen Energy 33, 1834-1844 (2008)

25. H. Mahcene, H.B. Moussa, H. Bouguettaia, D. Bechki, S. Babay, M. Salah Meftah, Study of species, temperature distributions and the solid oxide fuel cells performance in a 2-D model, Int. J. Hydrogen Energy 36, 4244-4252 (2011)

26. M. Andresson, J. Yuan, Sundén, SOFC modeling considering hydrogen and carbon monoxide as electrochemical reactants, J. Power Sources 232, 42-54 (2013)

27. S. Yang, Electrochemical analysis of an anode-supported SOFC, Int. J. Electrochem. Sci. 8, 2330-2344 (2013)

28. R.P. O'Hayre, Fuel cells for electrochemical energy conversion, EPJ Web Confer. 148, 00013 (2017)

29. Y. Sahli, H.B. Moussa, B. Zitouni, Optimization study of the produced electric power by SOFCs, Int. J. Hydrogen Energy (2018)

30. Y. Wang, R. Zhan, Y. Qin, G. Zhang, Q. Du, K. Jiao, Threedimensional modeling of pressure effect on operating characteristics and performance of solid oxide fuel cell, Int. J. Hydrogen Energy (2018)

31. J. Zhang, L. Lei, D. Liu, F. Zhao, F. Chen, H. Wang, Numerical investigation of solid oxide electrolysis cells for hydrogen production applied with different continuity expressions, Energy Convers. Manag. 149, 646-659 (2017) 
32. M. Ni, Thermo-electrochemical modeling of ammonia-fueled solid oxide fuel cells considering ammonia thermal decomposition in the anode, Int. J. Hydrogen Energy 36, 3153-3166 (2011)

33. M. Ni, 2D thermal-fluid modeling and parametric analysis of a planar solid oxide fuel cell, Energy Convers. Manag. 51, 714-721 (2010)

34. M.E. Chelmehsara, J. Mahmoudimehr, Techno-economic comparison of anode-supported, cathode-supported, and electrolyte-supported SOFCs, Int. J. Hydrogen Energy (2018)

35. H. Paradis, M. Andersson, B. Sundén, Modeling of mass and charge transport in a solid oxide fuel cell anode structure by a 3D lattice Boltzmann approach, Heat Mass Transfer (2015)

36. A. Chaisantikulwat, C. Diaz-Goano, E.S. Meadows, Dynamic modelling and control of planar anode-supported solid oxide fuel cell, Comput. Chem. Eng. 32, 2365-2381 (2008)

37. Y.M. Barzi, A. Raoufi, N.M. Rasi, S. Davari, Three dimensional simulation of a counter-flow planar solid oxide fuel cell, ECS Trans. 35, 1021-1033 (2011)

38. M. Saied et al., Investigations of solid oxide fuel cells with functionally graded electrodes for high performance and safe thermal stress, Int. J. Hydrogen Energy 42, 15887-15902 (2017)

39. A. Arvay et al., Convergence criteria establishment for 3D simulation of proton exchange membrane fuel cell, Int. J. Hydrogen Energy 37, 2482-2489 (2011)

40. M. Chyu, Numerical modeling of transport phenomena in solid oxide fuel cells, In 2005 Taiwan Solid Oxide Fuel Cell Symposium (2005)
41. G. Anandakumar, N. Li, A. Verma, P. Singh, J.H. Kim, Thermal stress and probability of failure analyses of functionally graded solid oxide fuel cells, J. Power Sources 195, 6659-6670 (2010)

42. P. Costamagna, K. Honegger, Modeling of solid oxide heat exchanger integrated stacks and simulation at high fuel utilization, J. Electrochem. Soc. 145, 3995-4007 (1998)

43. J.R. Ferguson, J.M. Fiard, R. Herbin, Three-dimensional numerical simulation for various geometries of solid oxide fuel cells, J. Power Sources 58, 109-122 (1996)

44. Z. Qu, P. Aravind, S. Boksteen, N. Dekker, A. Janssen, N. Woudstra et al., Three-dimensional computational fluid dynamics modeling of anode-supported planar SOFC, Int. J. Hydrogen Energy 36, 10209-10220 (2011)

45. M.M. Hussain, X. Li, I. Dincer, Mathematical modeling of planar solid oxide fuel cells, J. Power Sources 161, 1012-1022 (2006)

46. K. Keegan, M. Khaleel et al., Analysis of a planar solid oxide fuel cell based automotive auxiliary power unit, SAE Technical Paper Series 2002-01-0413 (2002)

47. B. Zitouni, H. Ben-Moussa et al., Temperature field, $\mathrm{H}_{2}$ and $\mathrm{H}_{2} \mathrm{O}$ mass transfer in SOFC single cell: electrode and electrolyte thickness effects, Int. J. Hydrogen Energy 34, 5032-5092 (2009)

48. B. Zitouni, G.M. Andreadis et al., Two-dimensional numerical study of temperature field in an anode supported planar SOFC: effect of the chemical reaction, Int. J. Hydrogen Energy 36, 4228-4235 (2001)

Cite this article as: Sabrina Horr, Hocine Mohcene, Hamza Bouguettaia, Hocine Ben Moussa, Performance analysis of AS-SOFC fuel cell combining single and sinusoidal flow field: numerical study, Renew. Energy Environ. Sustain. 6, 18 (2021) 